\title{
Reinterpreting Advice and Consent: A Congressional Fast Track for Arms Control Treaties
}

\author{
Ronald A. Lehmann
}

The Reagan Administration's interpretation of the 1972 Anti-Ballistic Missile (ABM) Treaty, ${ }^{1}$ allowing development and deployment of the Strategic Defense Initiative (SDI), raised difficult questions about the relative scope of presidential and congressional powers to interpret treaties. ${ }^{2}$ Administration opponents, led by Democratic Senator Sam Nunn, characterized the Reagan understanding of the ABM Treaty as a "reinterpretation"-a departure from the Nixon Administration's expressed understanding of the signatories' intent to limit development, testing, and deployment of "exotic" ABM systems that are not fixed and land-based."

1. Treaty on the Limitation of Anti-Ballistic Missile Systems, May 26, 1972, United StatesUSSR, 23 U.S.T. 3435, T.I.A.S. No. 7503 [hereinafter ABM Treaty].

2. The scholarly literature on the Reagan interpretation includes R. GARTHOFF, Policy VersuS THE LAW: THE REINTERPRETATION OF THE ABM TrEATY (1987); Chayes \& Chayes, Testing and Development of "Exotic" Systems Under the ABM Treaty: The Great Reinterpretation Caper, 99 HaRv. L. Rev. 1956 (1986); Kennedy, Treaty Interpretation by the Executive Branch: The ABM Treaty and "Star Wars" Testing and Development, 80 AM. J. INT'L L. 854 (1986); and Sherr, Sound Legal Reasoning or Policy Expedient, 11 INT'L SECuRITy 71 (1986-87). In addition, Abraham Sofaer, the State Department's Legal Adviser, and Senator Sam Nunn, both personally involved in the controversy, have written widely about it. E.g., Nunn, The ABM Reinterpretation Issue, Wash. Q., Autumn 1987, at 45; Sofaer, The ABM Treaty and the Strategic Defense Initiative, 99 Harv. L. Rev. 1972 (1986); Sofaer, The ABM Treaty: Legal Analysis in the Political Cauldron, WASH. Q., Autumn 1987, at 59.

3. The provisions at issue are Articles II, III, IV, V(1) of the ABM Treaty, and Agreed Statement D, appended to the Treaty. ABM Treaty, supra note 1, 23 U.S.T. at 3439-41, 3456. For statements opposing the Reagan Administration's interpretation of these provisions, see, e.g., Nunn, Interpretation of the ABM Treaty 1-6 (May 19, 1987), reprinted in The ABM Treaty and the Constitution: Joint Hearings Before the Senate Comm. on Foreign Relations and the Senate Comm. 
The Reagan Administration asserted that the Senate's failure in 1972 to condition its consent on an expansive definition of "exotics" allows the President wide interpretive leeway. ${ }^{4}$

This dispute, still not decisively resolved, called into question the efficacy of the advice and consent process itself, and underscored the precarious balance of treaty power between the President and the Senate. ${ }^{5}$ The President, by virtue of his superior access to information in the negotiating record, enjoys substantial unilateral control over United States treaty interpretation. To counteract this advantage, the Senate is able-and has recently threatened - to deny consent to a later treaty in order to display its disagreement with the President's reinterpretation of a prior one. ${ }^{6}$ Furthermore, Congress may, if necessary, withhold some of the appropriations or legal instruments necessary to the President for full implementation of the treaty. ${ }^{7}$ Such actions, however, can embarrass the President

on the Judiciary, 100th Cong., 1st Sess. 559, 560-65 (1987) [hereinafter ABM Hearings]; N.Y. Times, Sept. 22, 1987, at A15, col. 1. This Note uses the term "reinterpretation" as a shorthand to describe the situation in which the Senate, when it approves a treaty, believes that the treaty carries one interpretation, but the President subsequently claims that it has a materially different meaning. See Senate Comm. on Foreign Relations, The ABM Treaty Interpretation Resolution, S. ReP. No. 164, 100th Cong., 1st Sess. 48 (1987) [hereinafter ABM Resolution RePoRT].

4. Sofaer, Legal Analysis in the Political Cauldron, supra note 2, at 69-72; N.Y. Times, supra note 3 , at $\mathrm{A} 15$, col. 1 .

5. The Constitution provides that the President "shall have Power, by and with the Advice and Consent of the Senate, to make Treaties, provided two thirds of the Senators present concur." U.S. ConsT. art. II, $\S 2$, cl. 2.

6. In September 1987 the Senate Foreign Relations Committee threatened to delay or even refuse consent to the then-unsigned, uncompleted Intermediate Range Nuclear Force (INF) Treaty, 27 I.L.M. 84 (1988). The Committee reported that "the Administration's theory of treatymaking, having cast a dark shadow over the Senate's consideration of all future treaties, could severely complicate and greatly prolong the Committee's consideration of an INF treaty-and thereby jeopardize early ratification of that treaty." ABM REsolution REPORT, supra note 3, at 66 . When the INF Treaty came up for Senate approval, the Committee threatened again to delay its passage unless the Administration confirmed that the President would not reinterpret treaties without Senate consent. Without such an assurance, Committee Democrats stated, they would be forced to attach numerous clarifications and understandings to the INF Treaty. N.Y. Times, Feb. 6, 1988, at A1, col. 3. Although the Senators and the Administration reached a compromise over the interpretation of the INF Treaty, see Letter from Secretary of State George Shultz to Senator Sam Nunn (Feb. 9, 1988), reprinted in SENATE Comm. on Foreign Relations, The INF Treaty, S. Exec. ReP. No. 15, 100th Cong., $2 d$ Sess. 442 (1988) [hereinafter INF REPORT] (Reagan Administration "will in no way depart" from meaning of INF Treaty presented to Senate), the larger constitutional issue remained unresolved. When the Senate ultimately approved the INF Treaty, it attached an unusual condition stating explicitly that the Treaty's interpretation would "accord[ ] with the common understanding of the Treaty shared by the President and the Senate at the time the Senate gave its advice and consent to ratification[,]" based in part on "the authoritative representations which were provided by the President and his representatives to the Senate and its Committees. . . "134 ConG. REC. S6724 (daily ed. May 26, 1988). See infra note 76 (describing political situation surrounding condition). Although the President accepted this condition when he ratified the treaty with the Soviet Union, he subsequently stated that the condition had no effect on his "constitutional powers and responsibilities." President's Message to the Senate on the Soviet-United States Intermediate-Range Nuclear Force Treaty, 24 Weekly Comp. Pres. Doc. 779, 780 (June 10, 1988).

7. But see Restatement (THIRD) of Foreign Relations LAw § 111 reporters' note 7 (1987) [hereinafter Restatement]; L. Henkin, Foreign AfFairs and the Constitution 109, 161-62 (1972) (withholding of appropriations rare because considered inconsistent with Congress' sense of duty). 
and the country, cost the United States international credibility, and cripple American foreign policy.

Although the constitutional structure makes some of these tensions inevitable, the present level of antagonism between the President and the Senate in the advice and consent process damages the United States' ability to function effectively in the international community. Potential treaty partners may find little value in negotiating complex agreements with the United States only to have them derailed by internal American institutional disputes. As a step towards a more cooperative relationship between the executive and the legislature in foreign affairs, this Note proposes a new option for Senate consent to arms control treaties. ${ }^{8}$ According to this scheme, if the Senate evaluates the treaty on a "fast track," guaranteeing a vote within a specified number of days on an unamended agreement, the President would in exchange consult closely during negotiations with members of the Senate Foreign Relations Committee. He would also submit to the Senate an executive annotation of the treaty and its negotiating record; this document would be more thorough and detailed than the treaty analysis that the executive branch now sends to the Senate.

Section I of the Note explains how the ABM reinterpretation episode suggests a need for more informed Senate consent. ${ }^{2}$ Section II describes existing procedures designed to make Senate consent meaningful and informed. Section III analyzes the factors hindering the Senate's ability to provide informed consent. Section IV presents the fast track/executive annotation option as a method of reconciling competing congressional and presidential interests in the arms control treaty ratification process.

\section{The ABM Interpretation ConTroversy}

The United States and the Soviet Union signed and ratified the ABM Treaty in 1972 to reduce and restrict deployment of anti-ballistic weapons defense systems. ${ }^{10}$ Several of its provisions bear on development, testing,

8. Arms control remains one area where the President is likely to continue to make agreements that require Senate advice and consent, rather than to act through less formal instruments, such as executive agreements, in which the Senate's role is reduced. See infra text accompanying notes 28-30.

9. This argument focuses on the systemic weaknesses in the advice and consent process. There is, however, a plausible argument that the ABM reinterpretation controversy was an aberration, stemming from specific policy considerations (developing a legal argument to justify Star Wars), an unusually vague treaty (the $A B M$ ), a now chastened presidency (that will not attempt future reinterpretations), and a wiser Senate (that will not attempt to enforce its views by threatening to reject future treaties, see supra note 6). This scenario is unconvincing because the Reagan Administration attempted more than one reinterpretation, Rainbow Navigation v. Department of the Navy, 686 F. Supp. 354, 357-58 (D.D.C. 1988), and because reinterpretation is one constitutionally significant example of recent presidential "gambits to terminate, modify, selectively nullify, or circumvent existing treaties without Congress' prior consent." Koh, Why the President (Almost) Always Wins in Foreign Affairs: Lessons of the Iran-Contra Affair, 97 YALE L.J. 1255, 1262 (1988) (footnotes omitted) [hereinafter Koh, Iran-Contra]; see also Koh, Remarks on the Treaty Power, 43 U. MIAMI L. REv. 100, 106 (forthcoming 1988) (arguing that "gambits" threaten congressional role in treaty process).

10. Message to the Senate Transmitting the Antiballistic Missile Treaty and the Interim Agree- 
and deployment of future systems. ${ }^{11}$ In October 1985, the Reagan Administration announced publicly that the Treaty permitted development and testing of SDI weaponry. ${ }^{12}$ This contention sparked a heated debate not only about the true meaning of the treaty's text and negotiating record, but also about major constitutional principles.

\section{A. The Reagan Administration View}

In brief, the Administration argued that the Senate's 1972 ratification record did not bind later presidents to specific interpretations of the ABM Treaty's provisions dictating distinct treatment for systems based on "other physical principles." Nis Nixon Administration witnesses presented "inconsistent and ambiguous" testimony at the time, and the Senate did not explicitly condition its consent on a particular understanding about future "exotics."14 More generally, the Reagan view held, executive statements during Senate ratification hearings should not determine the President's obligations in implementing the treaty. If such testimony were decisive, the Senate would have to approve every presidential implementation that called into question a statement in the negotiating record. ${ }^{15}$

These arguments rest on the idea that "the constitutional division of treaty-making responsibility between the Senate and the President is essentially the reverse of the division of law-making authority, with the President drafting the treaty and the Senate holding the authority to grant or deny approval."16 The resulting deference to the President's interpretation of a treaty ${ }^{17}$ also owes its doctrinal tenacity to Justice Sutherland's

ment on Strategic Offensive Arms, 1972 PuB. PAPERs 674 (June 13, 1972) [hereinafter SALT I Letter of Transmittal] (two-page letter describing merits of ABM Treaty but not discussing future use of "exotics").

11. See supra note 3 (listing controversial provisions).

12. 85 Department of State Bull. No. 2105, at 33 (Dec. 1985) (transcript of television interview with Robert McFarlane, President's Assistant for National Security Affairs). Until October 1985 the Administration had justified SDI on the grounds that it was limited to "research," which-unlike "development"-was allowed by the Treaty. Chayes \& Chayes, supra note 2, at 1957; Nunn, supra note 3, at 4, reprinted in $A B M$ Hearings, supra note 3, at 563.

13. ABM Treaty, supra note 1 , at 3456 (Agreed Statement D).

14. Letter from A.B. Culvahouse, Counsel to the President, to Senator Richard Lugar (Mar. 17, 1988), reprinted in INF REPORT, supra note 6, at 443-45 (1988).

15. Id. at 444 .

16. Memorandum from Charles J. Cooper, Assistant Attorney General, Office of Legal Counsel, to Abraham D. Sofaer, Legal Adviser, Department of State 5 (Apr. 9, 1987), reprinted in OfFice OF the Legal Adviser, Department of State, The ABM Treaty Part II: Ratification ProCESS app. C (May 11, 1987) [hereinafter Cooper Memorandum]; see generally RESTATEMENT, supra note $7, \S 1$ reporters' notes 1,2 (comparing presidential and congressional functions in domestic and foreign affairs).

17. See. e.g., O'Connor v. United States, 479 U.S. 27, 32-33 (1986) (according substantial weight to executive interpretation of treaties); Sumitomo Shoji Am., Inc. v. Avagliano, 457 U.S. 176 (1982) (same); Zschernig v. Miller, 389 U.S. 429 (1968) (same); Factor v. Laubenheimer, 290 U.S. 276 (1933) (same); Restatement, supra note 7, §326 ("The President has authority to determine the interpretation of an international agreement to be asserted by the United States in its relations with other states."); see also Kolovrat v. Oregon, 366 U.S. 187, 194 (1961) (according great weight to treaty interpretation by implementing executive agency). 
famous dictum in United States v. Curtiss-Wright Export Corp. that the President is the "sole organ of the federal government in the field of foreign relations." ${ }^{18}$ Nevertheless, even to advocates of a broad executive foreign affairs power,

[A] President could not negotiate a treaty with other nations on the basis of one understanding of its import, submit the treaty to the Senate on a wholly different understanding, and then, in implementing the treaty, rely solely on the understanding he had reached with the other parties. . . . Such results would essentially eviscerate the Senate's constitutional advice and consent role. . . . 19

\section{B. The Opposing View}

The Reagan Administration's congressional opponents believed that the $A B M$ reinterpretation was unprecedented ${ }^{20}$ and sharply threatened the Senate's interest in a robust and meaningful advice and consent process. ${ }^{21}$ Viewing the President and Senate as partners in treaty-making, they contended that the tenor of executive testimony provides a guide to the Senate's implicit understanding of the treaty to which it consents, often without access to the "negotiating record." 22 To protect the Senate's legitimate

18. 299 U.S. 304,320 (1936). The Court recently reaffirmed the President's special role in forcign affairs in Goldwater v. Carter, 444 U.S. 996, 1000 n.1 (1979) (Powell, J., concurring) (citing Curtiss-Wright for proposition that in foreign affairs, Congress gives President discretion "that otherwise might run afoul of the nondelegation doctrine").

19. Cooper Memorandum, supra note 16, at 14. This "good faith" standard for presidential treaty interpretation is open to dispute. Professor Henkin has argued for a more objective guideline providing that "[t]he President can only make a treaty that means what the Senate understood the treaty to mean when the Senate gave its consent." ABM RESOLUTION REPORT, supra note 3, at 49. Henkin's view informs the RESTATEMENT, which states that "[w] then the Senate gives its advice and consent to a treaty on the basis of a particular understanding of its meaning, the President, if he makes the treaty, must do so on the basis of the Senate's understanding." Restatement, supra note 7, § 314(2). See also Rainbow Navigation v. Department of the Navy, 686 F. Supp. 354, 357-58 n.17 (D.D.C. 1988) (citing with approval Henkin and RESTATEMENT).

20. ABM RESOLUTION REPORT, supra note 3, at 48 ("The committee is aware of no instance in which a treaty was reasonably supposed by the Senate, when it consented to ratification, to mean one thing, and it was argued later by the Executive to mean something altogether different.") (emphasis in original).

21. INF REPORT, supta note 6, at 91 (Reagan Administration claims about congressional and executive roles in treaty interpretation would make Senate "on-looker of secondary status" in consent process). The arguments of the Reagan opponents are constitutionally suspect to the extent that they require a Senate role in the performance of treaties. See L. Henkin, supra note 7, at 136, 164 (Senate has no authoritative voice in acting upon or repealing a treaty).

22. INF REPORT, supra note 6 , at $87-88,93$. "Negotiating record" is a term of art referring to the notes, memoranda, or other documents that the treaty parties agree reflect their intent. The completeness of the record is necessarily contingent and is not ensured by a subsequent search for documents in the government offices of one treaty party. ABM RESOLUTION REPORT, supra note 3, at 50. Presidents, moreover, provide the Senate with different measures of information for different treaties. Which documents constitute the "record" and which documents are relevant for Senate perusal are, therefore, relative considerations. During the ABM Treaty approval process, senators were apparently forced to base their opinions upon testimony by executive officials, who alone had access to the negotiating record. Id. at 51 ("So far as the Committee can determine, no member of the Senate was given access to any 'negotiating record' at the time the Senate considered the ABM Treaty, and the 
role, executive testimony must "remain available as powerful evidence of a treaty's meaning in the event of an interpretive dispute among nations."23 Congress' power to pass a later statute, however, is not a sufficient threat to enforce the Senate's understanding of a treaty's meaning and might force the United States to default on its international obligations. ${ }^{24}$

Opponents of the Reagan reinterpretation have posited a number of further arguments against presidential treaty reinterpretations. First, as the INF Treaty experience suggests, future Senates might be willing to derail subsequent treaties in the face of executive reinterpretations of earlier ones. ${ }^{25}$ Second, presidential reinterpretations would encourage, perhaps even compel, the Senate to incorporate numerous amendments or understandings into future treaties and thereby greatly delay the advice and consent process. ${ }^{28}$ Finally, the institutionalized release of full, confidential negotiating records could chill the candid exchanges necessary for successful negotiations in the future. ${ }^{27}$

\section{G. The Constitutional Battleground}

The recent $A B M$ debate illustrates the serious constitutional and institutional concerns that presidential treaty reinterpretations could raise. Even though the United States now relies on treaties far less frequently than on other instruments for international agreement-making, ${ }^{28}$ the treaty process offers a solemnity and dignity that other instruments lack. ${ }^{29}$ Presidents submit international agreements for treaty advice and consent to avoid challenges to the accord's constitutional effectiveness. ${ }^{30}$ Presidential actions that undercut Senate advice and consent place at risk an approval process well suited for major international accords, such as arms

Reagan Administration has not argued otherwise.").

23. Nunn, supra note 3, at 59, reprinted in ABM Hearings, supra note 3, at 618.

24. L. Henkin, supra note 7, at 164; see also Henkin, The Constitution and United States Sovereignty: A Century of Chinese Exclusion and its Progeny, $100 \mathrm{HARv}$. L. Rev. 852, 871-72 (1987) (arguing against last-in-time rule on grounds of treaties' "sanctity" and Framers' intent that Congress not have authority to disregard United States' international obligations). One remedy to this situation is for the President, consistent with his power under United States law, to terminate or suspend the treaty. RestatemENT, supra note 7, § 339. This authority, while not explicit in the Constitution, was affirmed implicitly, if not decided conclusively, in Goldwater v. Carter, 444 U.S. 996 (1979) (finding Senator's claim against President for termination of treaty non-justiciable). For literature surveys concerning Goldwater, see Glennon, Treaty Process Reform: Saving Constitutionalism Without Destroying Diplomacy, 52 U. Cin. L. Rev. 84, 87 n.15 (1983); Comment, Resolving Treaty Termination Disputes, 129 U. PA. L. Rev. 1189, 1192 n.22 (1981).

25. See supra note 6 (describing INF Treaty advice and consent proceedings).

26. ABM Resolution RePoR'T, supra note 3, at 53.

27. Id.

28. Staff of Senate Comm. on Foreign Relations, 98th Cong., 2D Sess., Treaties and Other International Agreements: The Role of the United States Senate 70 n.55 (Comm. Print 1984) [hereinafter Treaties and AGreements] (prepared by Congressional Research Service) (executive agreements outnumbered treaties by seventeen to one in 1972).

29. L. Henkin, supra note 7, at 184. For example, no President has yet concluded an arms control accord in anything other than treaty form.

30. Id. at 183-84. 
control agreements, whose legitimacy is greatly strengthened by formal, constitutionally mandated Senate consent.

\section{The Treaty Consent Process}

\section{A. The Senate's Task}

The Senate's role in providing advice and consent to treaties is the product of two centuries of practice. Despite the Framers' vision of Senate participation in the actual making of treaties, ${ }^{31}$ the Senate currently advises and consents to ratification, generally without close involvement in negotiations. This situation evolved as the size of the Senate grew and the foreign affairs experience of the executive branch expanded. ${ }^{32}$ As the Framers predicted, the Senate's ability to transcend partisanship has supported its constitutional role in treaty-making. ${ }^{33}$

The general framework for Senate advice and consent is established by Senate Standing Rule 30.94 Although Senate Rules themselves are rarely changed, ${ }^{35}$ the Senate may implement internal procedural variations on these Rules, without presentment to the President, in order to accomplish its constitutional mandate. ${ }^{36}$ Alternatively, it may legislate procedures governing congressional approval or disapproval of presidential decisions. ${ }^{37}$

31. The Federalist No. 75, at 451-52 (A. Hamilton) (C. Rossiter ed. 1961) (arguing for joint congressional-executive exercise of treaty-making power). See Bestor, Respective Roles of Senate and President in the Making and Abrogation of Treaties-The Original Intent of the Framers of the Constitution Historically Examined, 55 WASH. L. REV. 1 (1979) (Framers intended congressionalexecutive cooperation in treatymaking).

32. L. HENKIN, supra note 7, at 131 (Senate finds Framers' conception of function unworkable, and now generally merely passes judgment on treaty, but does not advise during negotiations); TREATIES AND AGREEMENTS, supra note 28, at 104 ("[W] hat Presidents generally seek from Senators is not advice in advance, but consent after the fact-after negotiations are completed. Most treaties, therefore, engage the Senate only after their formal transmission by the President for approval.").

33. See THE Federalist No. 75 (A. Hamilton) (defending Senate integrity in advice and consent to treaties). While modern political science has attributed to Senators institutional loyalty, Huitt, Congress, the Durable Partner, in Lawmakers in a Changing World 9, 11-15 (E. Frank ed. 1966) (Congress and executive clearly distinct institutions), responsiveness to private interests, Macey, Promoting Public-Regarding Legislation Through Statutory Interpretation: An Interest Group Model, 86 Colum. L. REv. 223, 228 (1986) (while some legislation serves public interest, other is "amorally redistributive"); Sunstein, Interest Groups in American Public Law, 38 STaN. L. Rev. 29 (1985) (promoting Madisonian vision of legislators critically evaluating private preferences), and a dominant desire for reelection, D. Mayhew, Congress: The Electoral Connection 5-7 (1974), each insight merely reaffirms Hamilton's belief that the Senate will retain an important degree of independence from the President's desire for international accords. See infra note 76 (arguing that some Senate votes during INF Treaty approval process reflected non-partisan considerations).

34. Reprinted in Standing Rules of the Senate, S. Doc. No. 4, 100th Cong., 1st Sess. 45-46 (1987) [hereinafter Senate RuLEs].

35. F. Riddick, Senate Procedure, S. Doc. No. 2, 97th Cong., 1st Sess. 991 (1979).

36. U.S. Const. art. I, $\S 5$, cl. 2 ("Each House may determine the Rules of its Proceedings. . . "); see Meyer, Congressional Control of Foreign Assistance, 13 YALE J. INT'L L. 69, 98-99 nn.140-41 (1988).

37. For example, as described in Section IV(A)(2) infra, Congress incorporated a fast track into the Trade Acts of 1974 and 1984, which were signed by the President. See Koh, Congressional Controls on Presidential Trade Policymaking After I.N.S. v. Chadha, 18 N.Y.U. J. INT'L L. \& PoL. 1191, 1202-03 (1986) [hereinafter Koh, Congressional Controls]. 
Inherent in advice and consent, whatever its formal details, is the idea that it should be meaningful and, as a consequence, informed. To that end, current practice involves a series of procedures designed to produce a constitutional minimum of informed consent.

\section{B. The Operation of Advice and Consent}

The Senate typically receives the official title and text of the proposed treaty together with a Letter of Transmittal from the President requesting Senate advice and consent and a Letter of Submittal from the Secretary of State describing and analyzing the treaty's provisions. ${ }^{38}$ After the treaty's first reading, the Senate refers it to the Foreign Relations Committee, which conducts hearings with witnesses from the executive branch. ${ }^{39}$

During this stage of the advice and consent process, the Senate learns about the President's understanding of the treaty's intent. The Foreign Relations Committee composes a report, based on the executive's testimony, which "along with the President's initial 'Letter of Transmittal,' becomes the basic document of U.S. 'legislative history' on particular treaties since the negotiating records of the executive branch are generally unavailable to the public-and even to Congress itself."10

Upon completing its report to the whole Senate, the Foreign Relations Committee may recommend that the Senate approve the treaty only conditionally, adding amendments, reservations, understandings, or provisos. ${ }^{41}$ Amendments, which require changes in the text of the treaty, and reservations, which are qualifications or stipulations that generally do not alter the treaty's overall purpose, amount to counter-offers to the other signatories. ${ }^{42}$ Sometimes, amendments or reservations necessitate the reopening of negotiations. ${ }^{43}$ These devices, while diplomatically the most risky, are also the most restrictive of subsequent presidential interpretation because they are traditionally incorporated into the instrument of ratification exchanged with the other party. ${ }^{44}$ Should the Senate wish to elaborate or to interpret-rather than to change-a treaty provision, it may include under-

38. TREATIES AND AgReEments, supra note 28, at 105.

39. For a more detailed description of this process and a discussion of the relevant Senate Rules, see $i d$. at 105-09.

40. Id. at 108 .

41. For a more thorough discussion of these devices, see $i d$. at 109-12.

42. According to Eugene Rostow, amendments are more binding than reservations, which, he claims, "ha[ve] the same effect as a letter from my mother." TREATIES AND AGREEMENTs, supra note 28 , at 110 . Michael Glennon takes issue and argues that amendments and reservations have the same international effect. Glennon, The Senate Role in Treaty Ratification, 77 AM. J. INT'L L. 257, 264 (1983).

43. For example, during the Kennedy Round of multilateral trade negotiations, Congress required United States negotiators to reopen talks after they had "agreed to eliminate the American Selling Price . . method of customs valuation." Koh, Congressional Controls, supra note 37, at 1199 n.24.

44. Glennon, supra note 42, at 259-60. See also Restatement, supra note 7, § 314 (President must include reservation in instrument of ratification). "The President may also communicate a Senate qualification separately. . . ."Id. comment b. 
standings or provisos, which the President need not bring to the attention of the other signatories and which, therefore, offer him more interpretive leeway than reservations or amendments. ${ }^{45}$ To minimize the differences among these devices, the United States and its treaty partners stipulate in bilateral ratification protocols that each party expressly accepts the other's reservations, declarations, and understandings. ${ }^{46}$ Finally, beyond these formal means of restricting presidential interpretive power over treaties, the Senate has access to more informal mechanisms, including consultations with the executive and occasional participation in treaty negotiations. ${ }^{47}$

\section{The Problem of Uninformed Consent}

The procedures of treaty advice and consent allow the Senate a number of opportunities to gain information from the executive necessary for meaningful consent. Nonetheless, the President's information monopoly, which Congress generally has been unable to break, often leaves Congress under-informed ${ }^{48}$ The primary obstacles to Senate access to information are unnecessary presidential restrictions on information flow and judicial non-involvement in interbranch information disputes. As a result of these disadvantages, the Senate has been unable to provide consistently informed consent appropriate for the important agreements that the President submits for advice and consent.

\section{A. Presidential Control}

The President's monopoly of information distorts Congress' role in foreign affairs. ${ }^{4 \theta}$ The source of the imbalance is not the executive privilege doctrine per se, but unnecessary presidential withholding of information..$^{\mathbf{5 0}}$ The guidelines that have developed through prior assertions of executive privilege, however, indicate at least the outer contours of legitimate presidential restrictions on information-sharing. ${ }^{51}$ These parameters are flexi-

45. Treaties AND AGREements, supra note 28, at 110. But cf. Restatement, supra note 7, at $\$ 314$ (President must make treaty "on the basis of" Senate's understanding); id. $\$ 314$ comment d (President must respect Senate Foreign Relations Committee reports and Senate debate if they represent Senate understanding).

46. Id. $\S 314$ reporters' note 1.

47. Staff of House Comm. on Foreign Affairs, 98th Cong., 1st Sess., Strengthening

Executive-Legislative Consultation on Foreign Policy 14-21 (Comm. Print 1983).

48. Koh, Iran-Contra, supra note 9, at 1328-29.

49. Henkin, "A More Effective System" for Foreign Relations: The Constitutional Framework, in U.S. Commission ON THE ORganization OF THE Government FOR THE CONDUCT OF ForeigN Policy app. L at 19 (1975).

50. Id. at 14 n.32, 18 n.48; Koh, Iran-Contra, supra note 9, at 1329 n.345.

51. For a discussion of precedential decisions by the President to withhold information from Congress, compare Contempt of Congress: Report of the House Comm. Of Public Works and Transportation, 97th Cong., 2d Sess. 90, 91 (1982) (memorandum by Theodore B. Olson, Assistant Attorney General, December 14, 1982) ("Presidentially mandated refusals to disclose information to Congress-though infrequent-are by no means unprecedented. . . .") with $i d$. at 58,62 (memo- 
ble, ${ }^{52}$ but the heavy presumption in favor of the executive's control of information relating to foreign affairs places Congress at a serious disadvantage in the treaty context.

Although presidents have not claimed an absolute or unqualified right to withhold information from Congress, "military, diplomatic, or sensitive national security secrets" have received the most deference. ${ }^{.3}$ Generally, presidents try to avoid disclosing information that they feel could impede the executive branch from carrying out its duties. ${ }^{54}$ Aside from forcing the President to decide whether particular committees are trustworthy, confidential disclosures to Congress would also, from the President's perspective, improperly delegate authority to Congress. ${ }^{55}$ In the treaty context, the President's reluctance to release a treaty's complete negotiating history may also result from his desire to maximize interpretive flexibility or to conceal his own bargaining miscalculations.

As a general matter, Congress can raise a genuine claim to information in all circumstances involving legitimate legislative oversight. ${ }^{56}$ While the President may enjoy an information advantage, his dominant position is "not to be taken as minimizing the role of the legislature in foreign affairs." classified foreign affairs information through its intelligence, defense, and

randum from Stanley M. Brand, General Counsel to the Clerk, U.S. House of Representatives, to Rep. Elliott H. Levitas, December 8, 1982) ("[T]here is extensive judicial, statutory, and historic precedent for disclosure of the most sensitive material to congressional committees in executive session.").

52. Henkin, supra note 49 , at 14 ("The questions are how much and in what circumstances, and how and by whom these questions [of secrecy] shall be determined.").

53. United States v. Nixon, 418 U.S. 683, 706 (1974); see also United States v. Reynolds, 345 U.S. 1, 10 (1953) (privilege appropriate if revelation would expose sensitive military matters); Shane, Legal Disagreement and Negotiation in a Govermment of Laws: The Case of Executive Privilege Claims Against Congress, 71 MINN. L. REv. 461, 472 (1987) (courts show great deference to "narrower claims of privilege based on military and state secrets"). The Reagan Administration's policy on executive privilege provided that "[a] 'substantial question of executive privilege' exists if disclosure of the information requested might significantly impair the national security (including the conduct of foreign relations), the deliberative processes of the Executive Branch or other aspects of the performance of Executive Branch's constitutional duties." Memorandum from President Ronald Reagan to heads of executive departments (Nov. 4, 1982), reprinted in Nomination of Justice William Hubbs Rehnquist: Hearings Before the Senate Comm. on the Judiciary, 99th Cong., 2d Sess. 282-83 (1987) [hereinafter Rehnquist Nomination]. For the policies of previous Administrations, see The Petroleum Import Fee: Department of Energy Oversight: Hearings Before a Subcomm. of the House Comm. on Government Operations, 96th Cong., 2d Sess. 9, 10-19 (1980) (correspondence concerning executive privilege between Presidents and House Comm. on Government Operations, 1962-78).

54. See Rehnquist Nomination, supra note 53, at 282-83.

55. See Shane, supra note 53, at 483 . In the executive's view, the delegation problem arises because the integrity of executive power depends on the President's full protection of information, regardless of congressional promises to use the information properly.

56. See Eastland v. United States Servicemen's Fund, 421 U.S. 491, 503 (1975) (Congress has authority to act in "sphere of legitimate legislative activity").

57. Goldwater v. Carter, 617 F.2d 697, 709 (D.C. Cir.) (en banc), vacated, 444 U.S. 996 (1979). See also Memorandum by Stanley Brand, General Counsel to the Clerk, U.S. House of Representatives (Nov. 10, 1981), reprinted in Contempt of Congress: Hearings Before the Subcomm. on Oversight and Investigations of the House Comm. on Energy and Commerce, 97th Cong., 1st Sess. 108, 117 (1982) (in conduct of foreign relations, President acts as agent of Congress to implement legislative policy). 
foreign affairs committees. Moreover, the President may not use the Freedom of Information Act (FOIA) (58 $^{58}$ exemptions for material "kept secret in the interest of national security and foreign policy"58 and inter- or intraagency memoranda" as "authority to withhold information from Congress," since the FOIA exempts such materials from public disclosure only. $^{61}$

In the treaty context, the Senate and the President's interests in information collide. The President's monopoly of information, however, largely determines the outcome of the conflict. Ultimately, Congress has few weapons to overcome the President's sheer control of information, especially information that Congress does not even know to exist. This imbalance means that the President's decision as to what information should be withheld is usually decisive. ${ }^{62}$

\section{B. Judicial Non-Intervention}

Reluctant to find interbranch information disputes justiciable, ${ }^{63}$ courts have failed to provide Congress with a judicial weapon to counter presidential decisions to withhold information. To decide the merits of these cases, courts would be forced to weigh "such factors as the strength of Congress' need for the information in the request letters, the likelihood of a leak of the information in the Subcommittee's hands, and the seriousness of the harm to national security from such a release."

58. 5 U.S.C. $\S 552(1982)$.

59. Id. $\S 552(\mathrm{~b})(1)(\mathrm{A})$.

60. Id. $\$ 552(\mathrm{~b})(5)$.

61. Id. $\$ 552($ c). See Murphy v. Department of the Army, 613 F.2d 1151, 1158 (D.C. Cir. 1979) (Congress entitled to "widest possible access to executive branch information").

62. See N.Y. Times, Jan. 10, 1989, at A1, col. 3 (President appears responsible for decision to withhold classified information leading prosecution to drop charges against Lt. Col. Oliver North in trial stemming from Iran-Contra Affair).

63. In general, disputes between "coequal branches of our Government, each of which has resources available to protect and assert its interests[,]" face a heavy presumption of non-justiciability. Goldwater v. Carter, 444 U.S. 996, 1003-04 (1979) (plurality opinion). In addition, cases involving foreign affairs have traditionally carried a strong presumption of non-justiciability. See Chicago \& S. Air Lines v. Waterman S.S. Corp., 333 U.S. 103, 111 (1948); Shane, supra note 53, at 476-77 (discussing reasons for courts' non-confrontational attitude in executive privilege disputes). One court that did intervene in an unusual interbranch information dispute acted very tentatively. United States v. American Tel. \& Tel., 567 F.2d 121 (D.C. Cir. 1977) (appeal of United States v. American Tel. \& Tel., 551 F.2d 384 (D.C. Cir. 1976) after remand) (after encouraging Department of Justice to compromise with House subcommittee over subpoena, court ultimately intervened only on very narrow grounds); see Fein, Access to Classified Information: Constitutional and Statutory Dimensions, 26 WM. \& MARY L. Rev. 805, 840 (1985) (opinions in American Tel. \& Tel. are "woolly and temporizing"). Whatever its prudential merits, judicial reticence in interbranch disputes seems doctrinally suspect because of its reliance on the increasingly discredited political question doctrine. See Henkin, Is There a "Political Question" Doctrine?, 85 YALE L.J. 597, 622 (1976) (doctrine jurisprudentially unsound); Redish, Judicial Review and the "Political Question", 79 Nw. U.L. REv. 1031, 1060 (1985); see also Goldwater, 444 U.S. at 1001-02 (Powell, J., concurring) (citing inconsistent applications of doctrine); infra text accompanying notes 64-65 (discussing problems with finding of justiciability).

64. United States v. American Tel. \& Tel., 551 F.2d at 391. 
ever, precisely the types of calculations that courts are reluctant to make. ${ }^{.85}$ Even if courts, nevertheless, find interbranch information disputes justiciable and decide them in Congress' favor, Presidents might become more evasive about their activities and make extraordinary efforts to erase paper trails. $^{.6}$

\section{Proposal: The Optional Fast Track}

The President's information monopoly, together with judicial nonintervention in information conflicts, leaves Congress largely unable to gain access to information or to provide the meaningful consent that the advice and consent process requires. As a result, the President may find himself at a short-term advantage. To redress this situation, the Senate has threatened to delay consent to other treaties. ${ }^{67}$ Nonetheless, Congress remains under-informed in precisely those areas, such as arms control, where the President wants to employ the more dignified, solemn treaty process, rather than more informal instruments, such as executive agreements. To deal with these problems, this Section proposes an option, to be grafted onto existing procedures, that would produce meaningful, informed Senate consent in situations where such consent is constitutionally important. This procedure would also improve the prospects for passage of future treaties by preventing the treaty approval mechanism from becoming bogged down in disputes over access to information and contentious amendments. ${ }^{68}$ This Note proposes an internal Senate procedure, to be called the Optional Fast Track (OFT), that would create a new alternative for Senate advice and consent to arms control treaties. In brief, the plan, which would be separate from any particular treaty, allows the President expedited Senate consideration of signed arms control treaties in exchange for his promise to involve several Senators closely in the negotiations and to submit to the Senate an executive annotation of key provisions of the treaty and its negotiating record. ${ }^{68}$

The OFT would join a growing taxonomy of fast tracks. Under the first set of "automatic" fast tracks, such as those included in the Trade Act of $1974,{ }^{70}$ Congress promised the President that his initiatives would be "automatically" discharged from committee and voted up or down,

65. See supra note 63 (discussing arguments for non-justiciability).

66. Sofaer, Executive Power and the Control of Information: Practice Under the Framers, 1977 DUKE L.J. 1, 53.

67. See supra note 6; infra note 76 (describing threats to Senate consent to INF Treaty).

68. Speed is an important value in itself for the President because the longer a treaty stays in the Senate Foreign Relations Committee or on the Senate floor, the more likely it is to become a political football and the less likely it is to be approved relatively unscathed. See infra note 76 and accompanying text (describing delaying amendments).

69. The OFT is designed for arms control treaties, which are suited to take advantage of its benefits-speed, no-amendment consideration for the President, and greater information for the Senate.

70. 19 U.S.C. $\S \S 2191-2193$ (1982). 
without amendments, within a fixed time period. ${ }^{71}$ The subsequent "committee gatekeeping" fast track, such as the fast track contained in the Trade and Tariff Act of $1984,{ }^{72}$ enabled a congressional committee to bump a proposal from the fast track to the regular approval procedures. This option gives the President incentives to consult closely with Congress during negotiations. ${ }^{73}$

The OFT combines elements of both of these forms of the fast track. ${ }^{74}$ Seeking to restore the Senate's ability to provide informed consent, it maintains the Senate's treaty powers while honoring legitimate considerations of executive privilege. Unlike fast tracks in the war powers or foreign assistance contexts, where senators vote after the President's critical decision, the proposed treaty fast track allows senators to vote before ultimate presidential action. At the same time, the President's desire to maintain and benefit from the dignity and legitimacy of the treaty approval process for arms control accords should deter him from circumventing the OFT through executive agreements. ${ }^{75}$ The OFT also seems likely to reduce the chance that an arms control treaty will be held hostage to "killer amendments," amendments not germane to the treaty, or general interbranch antagonism. ${ }^{78}$

71. Koh, Iran-Contra, supra note 9, at 1332 n.358.

72. 19 U.S.C. $§ 2112$ (b)(4) (Supp. III 1985).

73. Koh, Iran-Contra, supra note 9, at 1333 n.360.

74. Fast-track consideration by the Senate does not appear to pose constitutional problems under INS v. Chadha, 462 U.S. 919 (1983), which held, in effect, that legislative vetoes are unconstitutional, id. at 959 (Powell, J., concurring) ("The Court's decision . . . apparently will invalidate every use of the legislative veto."). A legislative veto "allow[ed] [Congress], or one of its Houses or committees, to review and revoke the actions of federal agencies and executive departments." L. TRIBE, AMERICAN Constrmutronal LAw $\S 4-3$ (2d ed. 1988). While enjoying some of the flexibility of the legislative veto, a fast-track procedure "does not constitute a legislative veto, because it requires bicameral action and presentment to the President, albeit on an expedited basis." Koh, Iran-Contra, supra note 9, at 1332 n.358. Like the modified fast track in the Trade and Tariff Act of 1984, the committee disapproval mechanism of the OFT would be functionally similar to-but formally different from-the committee veto, which Chadha seemed to hold unconstitutional. Koh, Congressional Controls, supra note 37 , at $1216-17,1216$ n.76.

75. As a consequence, the OFT would undercut claims by the President that the Senate's lack of information precludes its meaningful consent to certain agreements.

76. See Gup, Scourge of the Senate, TIME, May 30, 1988, at 48; N.Y. Times, May 24, 1988, at A1, col. 6; id., May 21, 1988, at 3, col. 4 (describing killer amendments proposed for INF Treaty, and their defeat by wide margins). The Senate understanding about the INF Treaty's interpretation, attached to the Treaty itself, see supra note 6 , resulted from the Democratic opposition to the Administration's position in the ABM reinterpretation debate; it was highly controversial and threatened to delay-and possibly derail-the INF Treaty. L.A. Times, May 23, 1988, at 1, col. 6. The Senate vote on this amendment, with 19 Republicans joining 53 Democrats in its favor, 134 CoNG. REC. S6783-84 (daily ed. May 26, 1988), illustrates that senators may overcome party loyalty when they feel that the Senate's institutional integrity is threatened.

The Senate's independent behavior during the INF proceedings demonstrates the OFT's applicability to the arms control treaty context. The President's interest in avoiding killer amendments and unassociated amendments is apparent; senators concerned by the constitutional implications of the ABM reinterpretation have a renewed interest in the expanded information flow that the OFT provides. The OFT may also clear up Senate roadblocks to consideration of treaties. See Koh, IranContra, supra note 9, at 1332 n.358 (fast track's main advantage is "allow[ing] Congress to overcome both . . . political inertia and .. . procedural obstacles"). But see Meyer, supra note 36, at 98 n.139 (fast-track procedures better suited for congressional decisions requiring up-or-down votes, such 


\section{A. Expedited Consideration and Senatorial Involvement Under the OFT}

\section{General Considerations}

The OFT would not be part of a specific treaty or agreement, but would be an independent Senate procedure that is in place before negotiations begin. ${ }^{77}$ Either the President or Congress could invoke the OFT before negotiations begin, so that the Senate would fully enjoy the mechanism's information-sharing advantages. ${ }^{78}$ The OFT would establish time limits on debate in committee and on the floor of the Senate, as well as a bar against amendments, reservations, or understandings at any stage of Senate consideration. ${ }^{78}$ The Foreign Relations Committee would enjoy "gatekeeping" power, since the President would consult closely with its members before and during negotiations and would allow several of its members-perhaps its majority and minority leaders or whips-to be intimately involved in the talks. ${ }^{80}$ Closer congressional involvement in the negotiations might provide information to Congress that is unavailable under standard advice and consent procedures. ${ }^{81}$ Finally, under the OFT, the

as review of executive trade decisions, than for congressional decisions requiring opportunities for amendments, reservations, and understandings).

77. Although the Constitution guarantees Congress the power to regulate its internal proceedings, U.S. CoNST. art. I, $\S 5$, cl. 2, the Senate's ability to change any formally legislated procedures could be hampered by its subsequent inability to persuade the House and the President to agree to a new statute changing the rules again. Meyer, supra note 36, at 98 n.140. But see Koh, Iran-Contra, supra note 9, at $1332 \mathrm{n} .358$ (even statutory modifications in house rules "theoretically subject to change at any time by each house"). Consequently, the OFT proposal seems to carry fewer encumbrances in the form of an internal procedure, which, unlike a statute, need not meet bicameralism and presentment requirements. See Continuing Appropriations for Fiscal Year 1987, Pub. L. No. 99-591, $\S 101(\mathrm{k}), 100$ Stat. $3341,3341-304$ to -305 (1986) (containing exemplary language for OFT). Creating the OFT as an internal Senate procedure is not free of constitutional difficulties. The spirit of INS v. Chadha, 462 U.S. 919, 946-51 (1983), suggests that in areas of concurrent executive and congressional authority, some attention to formal procedures-presentment and bicameralism in the legislative context-is necessary. An internal Senate procedure governing the treaty process, even if it becomes operational only at the President's option, is arguably inconsistent with Chadha's formalism. This difficulty, however, seems less definite than the constitutional infirmity that statutory codification of Senate procedures appears certain to raise.

78. Similarly, at the invocation stage, either the President or the Senate could force the treaty onto the regular advice and consent track-the President by not involving senators in the negotiations and the Senate by not joining the talks.

79. See infra Section IV(A)(2) (describing OFT in detail). Because of its limited debate and noamendment provisions, the OFT could stifle congressional debate. Structuring the treaty fast track either in terms of a flexible number of legislative days or in terms of a sufficient number of calendar days, however, would mitigate this problem. Senators themselves seem best equipped to determine the precise number of days that would strike an appropriate balance between allowing sufficient debate and preserving the President's incentives for choosing the OFT.

80. The INF proceedings, see supra notes $6 \& 76$, demonstrate that the President has strong incentives to involve senators actively in negotiations, in order to make the treaty more likely to stay on the fast track and to preclude the risk that it will be defeated by killer or non-germane amendments. This sub-congressional delegation may raise constitutional difficulties pursuant to the spirit of Chadha, see supra note 74, and of Bowsher v. Synar, 478 U.S. 714 (1986) (congressional control over removal of official performing executive functions usurps executive power). Nonetheless, informal past experience, see supra text accompanying note 47 , suggests that a significant advisory role for a few senators during negotiations is consistent with constitutional intent.

81. Although the OFT enables the Senate to acquire more information than does standard advice 
Senate could vote, either in committee or after full house debate, to defeat the treaty outright or to transfer the treaty from the OFT to standard advice and consent in order to add amendments. ${ }^{82}$ Similarly, the Senate could encourage the President to choose the OFT for a particular arms control treaty by demonstrating a clear likelihood of approval after close congressional-executive cooperation during negotiations.

\section{Details of Operation: The Trade Fast Track Experience}

The fast-track procedures employed in the trade context should serve as a model for the details of expedited Senate consideration under the OFT. ${ }^{83}$ The Trade Act of $1974^{84}$ gave the President authority to negotiate trade agreements in exchange for Congress' assurance that it would vote within a specified time frame on an unamended accord. The Trade and Tariff Act of $1984^{86}$ altered the 1974 fast track in order to avoid problems of constitutionality and expand the scope of bilateral trade agreements. ${ }^{86}$

This "modified fast track" provides the model for the expedited consideration and senatorial involvement aspects of the OFT. It required the President to consult with the relevant House and Senate committees for sixty legislative days before giving ninety calendar days' notice of his intent to sign a trade agreement. ${ }^{87}$ Already during the ninety-day consultation period, the involved congressional committees had marked up the

and consent, the OFT is not meant to legitimate presidential coverups in non-fast-track circumstances. Presidents are likely not to release any more information than they feel necessary; as a result, standard advice and consent will inevitably lead to more limited Senate access to information than the OFT.

82. Since the present treaty advice and consent process seems slow and amendment-ridden, it is unlikely that the President would avoid invoking the OFT in order to expedite the existing approval mechanism. Since under the OFT the Senate retains the option to derail the treaty, it does not risk capitulating in advance to language and intent without the opportunity for amendment.

83. See Koh, Congressional Controls, supra note 37, at 1219 ("The demonstrated effectiveness of the modified fast-track procedure in assuring congressional input into the U.S.-Canadian free trade negotiations may well inspire Congress to substitute it as the new technique of choice to restrain presidential negotiating authority in other fora."). Examples of fast-track mechanisms outside the trade area include the Comprehensive Anti-Apartheid Act of 1986, Pub. L. No. 99-440, §602, 100 Stat. 1086, 1112-14 (fast track provisions codified at 22 U.S.C. § 5112 (Supp. IV 1986)) (joint resolution authorizing presidential sanctions against South Africa or opposing presidential decision to terminate them), and the Continuing Appropriations for Fiscal Year 1987, Pub. L. Nos. 99-500, 99$591, \S 101(\mathrm{k}), 100$ Stat. 1783, 1783-304 to -305 , 100 Stat. 3341, 3341-304 to -305 (1986) (joint resolution disapproving aid to Nicaraguan rebels).

The most thorough description of the fast-track procedure, from which this Note draws heavily, is Koh, Congressional Controls, supra note 37, at 1200-21 (1986). See also Bello, The Tokyo Round and Bejond, 12 YALE J. INT'L L. 444, 448-51 (1987) (describing trade fast track); Koh, IranContra, supra note 9, at $1332 \mathrm{n.358}$ (same); Koh, The Legal Markets of International Trade: The U.S.-Canada Free Trade Agreement, 12 YALE J. INT'L L. 193, 205-18 (1987) (same); Meyer, supra note 36, at 97-99 (describing foreign assistance fast track); Note, Congress and Arms Sales: Tapping the Potential of the Fast-Track Guarantee Procedure, 97 YALE L.J. 1439, 1449-57 (1988) (applying trade fast track to arms sales legislation).

84. Pub. L. No. 93-618, 88 Stat. 1978 (codified at 19 U.S.C. $\S \S 2101-2487$ (1982)).

85. Pub. L. No. 98-573, 98 Stat. 2948 (codified as amended in scattered sections of 19 U.S.C.).

86. See Koh, Congressional Controls, supra note 37, at 1212 n.60 (discussing revisions of trade fast track). The OFT would not be part of specific treaties. See supra note 77 and accompanying text.

87. Under the OFT, only the Senate and its Foreign Relations Committee would be involved. 
President's trade bill so that when the bill was formally introduced, its chances of passage on the fast track were high. ${ }^{88}$ Congressional approval was then expedited so that the negotiated agreement and its implementing legislation were automatically discharged from the committee after fortyfive legislative days and were voted on by each house, without amendment, within an additional fifteen legislative days. ${ }^{89}$

\section{B. The Executive Annotation}

\section{Content of the Annotation}

In addition to expedited Senate consideration and Senate involvement in negotiations, the other distinctive feature of the OFT is the executive annotation, which the President, upon invoking or accepting the OFT, must promise to submit along with the treaty. The annotation provision of the OFT responds to the absence of clear executive testimony that was largely responsible for the $\mathrm{ABM}$ reinterpretation controversy..$^{90}$ The recent debate suggests that the Senate would be well served by a comprehensive statement from the President complementing the negotiating record, committing him to a particular understanding of ambiguous issues in the record, and reconciling different points of view about the treaty within the executive branch. ${ }^{91}$

The executive annotation would offer a more thorough analysis of the treaty than current Letters of Submittal and Transmittal, which tend not to include or comment on actual documents from the negotiating record. ${ }^{92}$

88. J. Jackson, J.-V. Louis \& M. Matsushita, Implementing the Tokyo Round: NATIONAL Constitutions and International Economic Rules 162-63 (1984). This procedure could be adopted to foster close Senate involvement in the drafting of the treaty.

89. Koh, Congressional Controls, supra note 37, at 1202 n.32, 1203 n.33 (citing statutory provisions).

90. See ABM Hearings, supra note 3, at 351, 373 (statement of Abraham Sofaer, Mar. 26, 1987) ("[E]rrors sometimes occur, people sometimes exaggerate, and misunderstandings take place."); Glennon, Interpreting "Interpretation": The President, The Senate, and When Treaty Interpretation Becomes Treaty Making, 20 U.C. DAvis L. REv. 913, 915 (1987) (Senate "misled" by testimony of Nixon Administration spokesmen concerning ABM Treaty).

91. As a by-product, the annotation might also encourage the different agencies of the United States Government interested in a treaty to agree to a particular interpretation. For example, where the Defense Department may seek a broad interpretation to allow build-up of a weapons system, the State Department-for diplomatic reasons-and the Treasury Department-for financial reasons-may favor a narrower reading. The executive branch's desire to speak with one voice in the annotation would encourage these agencies to find common ground; it could, however, also enable the Senate to play one agency or department against others. Since the annotation would be unavailable outside the Senate, see infra notes 97-102 and accompanying text, it would not embarrass or injure the United States internationally.

92. See, e.g., Treaty on the Limitation of Strategic Offensive Arms: Message to the Senate Transmitting the Treaty and Related Documents, 1979 PuB. Papers 1155 (June 22, 1979); Letter of Submittal, Secretary of State Cyrus Vance to President Jimmy Carter (undated) (describing and advocating Senate approval of SALT II), reprinted in TREATY ON THE LIMTTATION OF STRATEGIC Offensive Arms and Protocol Thereto (SALT II Treaty): Message from the President of THE UNITEd States, S. Exec. Y, 96th Cong., 1st Sess. v (1979); SALT I Letter of Transmittal, supra note 10; Letter of Submittal, Secretary of State William P. Rogers to President Richard Nixon, reprinted in The ABM TReaty and Interim Agreement and Associated Protocol: Mes- 
The annotation would be distinguished by the level of detail provided through primary source documents in the negotiating record, and by its attempt to project future problems. ${ }^{93}$ It would also point out purposeful ambiguities and omissions in the treaty. ${ }^{94}$ For prudential reasons, the President would not be required to include in the annotation deliberative internal legal memoranda about the treaty from the Offices of Legal Counsel in the State and Justice Departments. ${ }^{95}$ In order to afford senators the opportunity to point out problems in the annotation and, as a result, to increase the likelihood of the annotation's consistency with the negotiating record, the Senate should require the President to submit the annotation first as a draft at the beginning of the hearings and again in final form after executive testimony before the full Senate floor debate. ${ }^{96}$

\section{Risk of Disclosure}

The executive annotation should remain under seal in the White House so that United States treaty partners can feel assured that the confidentiality of negotiations is maintained. To preserve confidentiality, the Senate could adopt a number of measures, such as appending a secrecy injunction to the annotation allowing only senators and their staffs to read it, or requiring closed or executive sessions for hearings or floor debates dealing with the annotation. ${ }^{27}$ The Senate Rules provide that any senator who

Sage from the President of the United States, S. Exec. L, 92d Cong., 2d Sess. v (1972).

93. The comprehensive nature of the annotation might be analogized to the complete scope of the environmental impact statement that Judge Bazelon envisioned in Natural Resources Defense Council v. United States Nuclear Regulatory Comm., 685 F.2d 459 (D.C. Cir. 1982).

94. Current Letters of Transmittal and Submittal do not make a specific effort to address these issues. To discourage the President from glossing over them in the annotation the Senate retains the option to derail the treaty from the OFT. See supra text accompanying note 82.

95. Although the FOIA standards do not govern congressional information requests, 5 U.S.C. $\S$ 552(c) (1982), the President might refuse to include in the annotation deliberative documents, protected from public disclosure by the FOIA, that shed light on the decision-making process inside the executive branch. See Brinton v. Department of State, 636 F.2d 600, 605-06 (D.C. Cir. 1980); Mead Data Cent., Inc. v. United States Dep't of Air Force, 566 F.2d 242, 252-59 (D.C. Cir. 1977) (interand intra-agency exchanges of opinions part of deliberative process and in category of advisory material protected by FOIA); see also Note, The Applicability and Scope of the Attorney-Client Privilege in the Executive Branch of the Federal Government, 62 B.U.L. REv. 1003, 1015 n.72 (1982) (executive privilege protects communications from lawyer to agency); supra notes 58-61 and accompanying text (describing FOIA standards).

96. The draft would be discarded after Committee hearings and would carry no weight if, after approving the treaty, the Senate subsequently felt that the President was seeking to reinterpret it.

97. Senate Standing Rules 21, 26(5)(b), 30, reprinted in SENATE RuLES, supra note 34, at 15, 37-38, 45-46 (describing closed and executive sessions). See generally United States v. American Tel. \& Tel., 551 F.2d 384, 386-87 (D.C. Cir. 1976) (suggesting possible effectiveness of these devices); Fein, supra note 63 , at 816 \& n.51 (listing and discussing secrecy devices). The congressional committee investigating the Iran-Contra Affair cited American Tel. $\mathcal{E} T$ Tel. approvingly, perhaps suggesting that the information-sharing approach that the D.C. Circuit adopted in the domestic context was consistent with constitutionally mandated interbranch cooperation in foreign affairs. HouSE SELECT Comm. to Investigate Covert Arms Transactions with Iran and Senate Select Comm. on Secret Military Assistance to Iran and the Nicaraguan Opposition, Report of the Congressional Comms. Investigating the Iran-Contra Affair, S. ReP. No. 216, H.R. ReP. No. 433, 100th Cong., 1st Sess. 388 (1987).

Although the speech and debate clause protects any speech within the halls of Congress, U.S. 
discloses confidential Senate proceedings is liable for expulsion and punishment for contempt. ${ }^{98}$ The speech and debate clause, ${ }^{99}$ however, would probably protect a senator who read the executive annotation into the public record from civil or criminal liability; ${ }^{100}$ therefore, to strengthen its secrecy provisions, the OFT should mandate an automatic motion to censure senators placing any parts of the annotation in the Senate's public record. ${ }^{101}$ Any sacrifice of public disclosure that Congress accepts in order to ensure secrecy is likely to be small, since the information in the executive annotation would not have been immediately available to the public in any case. ${ }^{102}$

\section{Enforcing the Annotation: Another Look at the ABM Reinterpre- tation Controversy}

The President, of course, has incentives to make the annotation as vague as possible so as to maximize his future flexibility. ${ }^{103}$ Over time, moreover, the annotation and the negotiating record may conflict over particular issues, or the President may propound an interpretation of a question about which the annotation is silent. Had the OFT been in use in 1972, when the Senate approved the ABM Treaty, either of these scenarios might have occurred. The senators closely involved in the negotiations would have known, however, whether the annotation concealed or distorted crucial information in the negotiating record, and the current Senate could determine whether the subsequent reinterpretation was inconsistent with the annotation or negotiating record. ${ }^{104}$ If the annotation turned

CoNST. art. I, $\S 6, \mathrm{cl}$. 1, the Constitution recognizes that in certain circumstances Congress may have good reason not to publish its proceedings, U.S. CoNST. art. I, $\S 5, \mathrm{cl}$. 3. Secrecy, whether in the form of executive sessions or non-publication of debate, reduces the Senate's ability to exert pressure on the President through threats to make the contents of the summary publicly available. Nonetheless, the risk of a denial of appropriations over a treaty interpretation issue could expose the President to international embarrassment, which would redound to his detriment domestically as well. See supra text accompanying note 7.

98. Senate Rule $29, \S 5$, reprinted in SEnate Rules, supra note 34 , at 45 .

99. U.S. ConsT. art. I, $\S 6, \mathrm{cl} .1$.

100. See Gravel v. United States, 408 U.S. 606, 615-16 (1972) (speech and debate clause protects senator who reads classified Pentagon Papers into public record).

101. As "privileged business," this motion would receive immediate consideration. F. RIDDICK, supra note 35 , at 219 .

102. Whether courts would uphold the document's confidentiality is unclear. The FOIA's national security exception, 5 U.S.C. $\S 552(\mathrm{~b})(1)(A)(1982)$, would give them grounds to do so. Nonetheless, since the executive annotation is the executive's "final opinion" concerning a treaty, FOIA might not protect it from public disclosure. See Coastal States Gas Corp. v. Department of Energy, 617 F.2d 854, 866-69 (D.C. Cir. 1980) (explanation of agency policy in specific situation not privileged because it is not recommendation or predecisional document but discusses established policies).

103. A certain amount of ambiguity in the annotation is inevitable because of the omnipresent difficulties of abstractness and language in any international agreement. M. MCDougAL, H. LASSwell \& J. Mil.ler, The INTerpretation of Agreements and World Public Order: Principles of Content and Procedure xi (1967).

104. The annotation's value depends significantly on close scrutiny by the Senators involved in the negotiations. Since party loyalty and political sympathy might affect that scrutiny, those Senators involved in the negotiations should reflect the diversity of the full Senate. 
out to be deceptive, or the reinterpretation was inconsistent with the Senate's 1972 understanding of the Treaty, the Senate could deny appropriations necessary for programs implemented pursuant to the reinterpretation, refuse consent to future treaties submitted by the President under the OFT or under regular advice and consent procedures, and prevent the President from again benefitting from the OFT's speedy, no-amendment consideration.

Goldwater $v$. Carter ${ }^{105}$ suggests that a court would probably not enforce the annotation's interpretation against the President, at least as a matter of international law. ${ }^{108}$ Ultimately, however, complementary institutional goals and prerogatives provide the President and the Senate with substantial and persuasive incentives to fulfill their obligations under the OFT in good faith. While the President needs a treaty approval process that generates informed Senate advice and consent, ${ }^{107}$ the Senate is unlikely to complete its task properly without liberal access to information about the treaty and its negotiating record. ${ }^{108}$ At the same time, the President can refuse to involve senators or provide the annotation as the OFT requires, and the Senate can shift a treaty from fast-track to regular approval procedures. This balance of interests and options, rather than external powers of enforcement, ultimately sustains the OFT.

105. 444 U.S. 996 (1979).

106. In effect, then, the negotiating record would prevail over the annotation if the President propounded a reinterpretation that conflicted with the annotation. See supra note 24 (interbranch dispute over treaty termination non-justiciable).

The Supreme Court's recent reaffirmation of judicial "authority to construe treaties and executive agreements," Japan Whaling Ass'n v. American Cetacean Soc., 478 U.S. 221, 230 (1986), might provide grounds for a finding of justiciability if a court treated the dispute over the annotation's enforceability as a matter of treaty interpretation, rather than as an interbranch disagreement about foreign policy. While Goldwater makes such a finding unlikely, 444 U.S. at 1004 (Rehnquist, J., concurring) ("dispute between coequal branches" non-justiciable), a court reaching the merits might require the President to follow the annotation's interpretation on the grounds that the annotation constitutes domestic law, which the President has a duty to "faithfully execute," U.S. CoNST. art. II, $\S 1$, cl. 8. See Henkin, International Law as Law in the United States, 82 Mrch. L. Rev. 1555, 1567-69 (1982) (courts can enjoin President to observe domestic law but not international law). The court would probably have to consider the annotation in camera in order to protect post-negotiation secrecy, to prevent the relatively fixed interpretation of the annotation from becoming available to astute treaty partners who could apply it against the United States, and to preserve the President's incentive to opt for the OFT. Thus, closure seems not to pose a constitutional problem in this context, since even under the more restrictive criminal law standard, "[ $t$ ]he presumption of openness may be overcome . . . by an overriding interest based on findings that closure is essential to preserve higher values and is narrowly tailored to serve that interest." Press-Enterprise Co. v. Superior Court of Cal., 464 U.S. 501, 510 (1984). In these circumstances, in camera proceedings would not deprive the public of information, since the annotation's contents would not have become publicly available had the document not been the subject of litigation.

107. See supra Section $\mathrm{I}(\mathrm{C})$ (describing benefits of formal treaty advice and consent process).

108. See supra Section III (discussing reasons for-and consequences of-uninformed advice and consent). 


\section{CoNCLUSION}

In the $\mathrm{ABM}$ Treaty interpretation controversy, President Reagan claimed executive knowledge and Senate ignorance of the contents of the ABM Treaty's negotiating history in order to advance a new interpretation of the Treaty. As a result, he undercut the Senate's constitutional role in treaty advice and consent. Moreover, he jeopardized the collaborative intent behind the treaty approval mechanism, the prospects for future treaties, and the appropriations necessary to implement treaties currently in force.

The proposal presented in this Note seeks to redress the dangers of presidential reinterpretation. The OFT is presented as an option for a more collaborative treaty approval process, encouraging consultation and increased congressional participation in treaty-making while reducing the risk that the Senate will not approve an arms control treaty submitted by the President. It offers the Senate more complete and definitive information about the treaty's negotiating history without infringing on the President's legitimate executive privilege. Above all, the OFT seeks to foster a "problem-solving negotiating strategy"100 that takes into account the needs of the President and the Senate in creating a smoother and more satisfactory advice and consent process.

109. Shane, supra note 53, at 542 . 